\title{
Impact of Climatic Parameters on the Performance of Solar Photovoltaic (PV) Module in Niamey
}

\author{
Abdou Latif Bonkaney¹, Saidou Madougou², \\ Rabani Adamou 1,3 \\ ${ }^{1}$ Master Research Program Climate Change and Energy, UAM, Niamey, Niger \\ ${ }^{2}$ Ecole Normale Superieure, UAM, Niamey, Niger \\ ${ }^{3}$ Departments of Chemistry, UAM, Niamey, Niger \\ Email: babdoulatif@yahoo.fr
}

How to cite this paper: Bonkaney, A.L., Madougou, S. and Adamou, R. (2017) Impact of Climatic Parameters on the Performance of Solar Photovoltaic (PV) Module in Niamey. Smart Grid and Renewable Energy, 8, 379-393.

https://doi.org/10.4236/sgre.2017.812025

Received: October 8, 2017

Accepted: December 12, 2017

Published: December 25, 2017

Copyright $\odot 2017$ by authors and Scientific Research Publishing Inc. This work is licensed under the Creative Commons Attribution International License (CC BY 4.0).

http://creativecommons.org/licenses/by/4.0/

\begin{abstract}
The sensitivity of mono-crystalline solar PV module towards dust accumulation, ambient temperature, relative humidity, and cloud cover is investigated from May to August 2015 for Niamey's environment. Two solar modules with the same characteristics have been used to carry out the impacts of the dust on the solar PV module. One of the modules is being cleaned every morning and the second one was used for monitoring the effect of dust accumulation onto the surface of the unclean module for May and June. The ambient temperature around the solar PV module was recorded at the same time with the output voltage and the output current to assess the impacts of ambient temperature on the PV conversion efficiency. In addition to these field test measurements, the solar radiation data measured in National Center of Solar Energy (CNES) of Niamey were also used. Also the relative humidity for the study area data obtained NASA power agro-climatology website was used. Results show that the dust accumulation has the greatest impact on the performance of the PV module followed by temperature, relative humidity and cloud cover. Exposing the module in 23 days has reduced the energy output by $15.29 \%$. The power output and the conversion efficiency of the PV module have dropped by $2.6 \%$ and $0.49 \%$ respectively. The relative humidity also has reduced the energy output by $4.3 \mathrm{Wh} / \mathrm{m}^{2} /$ day.
\end{abstract}

\section{Keywords}

Mono-Crystalline Solar PV, Dust Accumulation, Ambient Temperature, Conversion Efficiency, Daily Energy Output 


\section{Introduction}

\subsection{Background}

The renewable energy resources are becoming the mainstream energy resource [1]. Among these renewable energy resources, the solar photovoltaic (PV) is the most promising resource [2]. Indeed, PV production has been increasing by an average of $20 \%$ each year since 2002, making it a fast-growing energy technology. However, in 2009, the global cumulative PV installations have exceeded 21 GW [3]. The energy system in Niger as in most of sub-Saharan countries is faced with a number of interrelated challenges: low energy access, insecure energy supply and growing environmental degradation.

The per capita electricity consumption in Niger was less than $50 \mathrm{kWh}$ and about $75 \%$ of the population does not have access to electricity [4].

However, the country is endowed with high potential renewable energy. According to solar map for Africa, the country has on average a daily radiation ranging from 6 to $7.5 \mathrm{kWh} / \mathrm{m}^{2} /$ day. This high potential in solar energy is underused. Still in 2012, the total installed PV capacity was over 4 MW with $2772 \mathrm{~kW}$ for telecommunications, $913 \mathrm{~kW}$ for water pumping, $199 \mathrm{~kW}$ in health sector, 88 $\mathrm{kW}$ for household, and $70 \mathrm{~kW}$ for education center [4]. The latest information on solar on Solar PV energy development was in 2014 with a total install capacity of 5.2 MW.

Nevertheless, there is a growing investment interest in PV grid connection and standalone system as the falling cost of PV in recent years brings the technology closer to grid parity in many parts of the world. Niger's high electricity generation cost is likely to provoke investor interest in introducing PV to the grid. Also policy makers in Niger widely acknowledge the important role that renewable energies can play in developing the power sector. Solar PV energy is being promoted as reliable energy source that can contribute to reducing dependence vis à vis of the imported electricity from Nigeria [4].

So in order to efficiently and economically use the photovoltaic solar energy, there is a need to study the environmental parameters that can negatively impact on its performance and to see how best one can reduce these impacts. Indeed, the solar modules are rated under standard test conditions (STC, irradiation = $1000 \mathrm{~W} / \mathrm{m}^{2}, \mathrm{Tc}=25^{\circ} \mathrm{C}, \mathrm{AM} 1.5$ ) [5]. These conditions are different outdoors. So studying the impact of ambient temperature, relative humidity, dust accumulation and cloud cover on the photovoltaic performance is of great important in a hot and dusty environment like Niamey. Studying the impacts of these environmental variables has already been done in some parts of the world [6] [7] [8]. Indeed, the performance of solar photovoltaic module is site specific. So, this paper presents the impacts of environmental parameters on the performance of solar PV module in Niamey and the daily energy that can be yielded from May to August.

\subsection{Aim and Objectives}

The aim of this study is to assess the impacts of climatic parameters on the per- 
formance of solar PV module under the environmental conditions of Niamey. In order to achieve this aim, the specific objectives have been achieved:

- Assess the impacts of climatic parameters (ambient temperature, relative humidity, cloud cover, and dust accumulation) on the performance of solar PV module.

- Estimate the daily energy yielded by the PV module under the environmental conditions of Niamey.

\section{Materials and Methods}

\subsection{Site of Study}

Two sites located in Niamey have been considered in this work. The National Center for Solar Energy $\left(\mathrm{CNES}, 2.107^{\circ} \mathrm{E}, 13.50^{\circ} \mathrm{N}\right)$ where global radiation is collected from a pyranometer with a datalogger and the roof of the was cal's building $\left(2.095^{\circ} \mathrm{E}, 13.51^{\circ} \mathrm{N}\right)$ where the PV power is measured each 30 minutes. This site has been chosen in order to avoid any perturbations (such as shading, animals, people...).

The two sites are shown in the Figure 1.

\subsection{Experimental Set Up}

Two PV modules (one is being cleaned every morning and other not cleaned) are installed on the roof of Wascal's building at the Faculty of Science and Techniques of ABDOUMOUMOUNI University independently from each other. Each one is set on a tilted metallic support of $15^{\circ}$ (this angle has been chosen regarding to the angle of the pyranometer installed in CNES). Cables were used to connect the modules to the charge regulators and from charge regulators to the LED lights and the battery in order to have a closed circuit. The charge regulators and the LED lights are fixed on a mockup placed where the measuring is performed.

The digital multi-meter used is a handheld 31/2 multi-meter for measuring DC and AC Voltage, DC and AC current, resistance, diode, transistor, frequency, capacitance and temperature. In this study, only DC current, DC voltage, and temperature were measured.

The Table 1 shows the error associated with the measurements.

The picture of the experimental set up is summarized in Figure 2.

\subsection{Measurement and Data Processing}

From the Figure 3 the ambient temperature around was recorded and also output current, and output voltage were recorded every thirty minutes for the two modules. This allowed the estimation of the power output and the dust accumulation effects on the solar PV output. The relative humidity data for the site is obtained from NASA power agro climatology http://power.larc.nasa.gov/common/php/Agro_ExSummary.php 


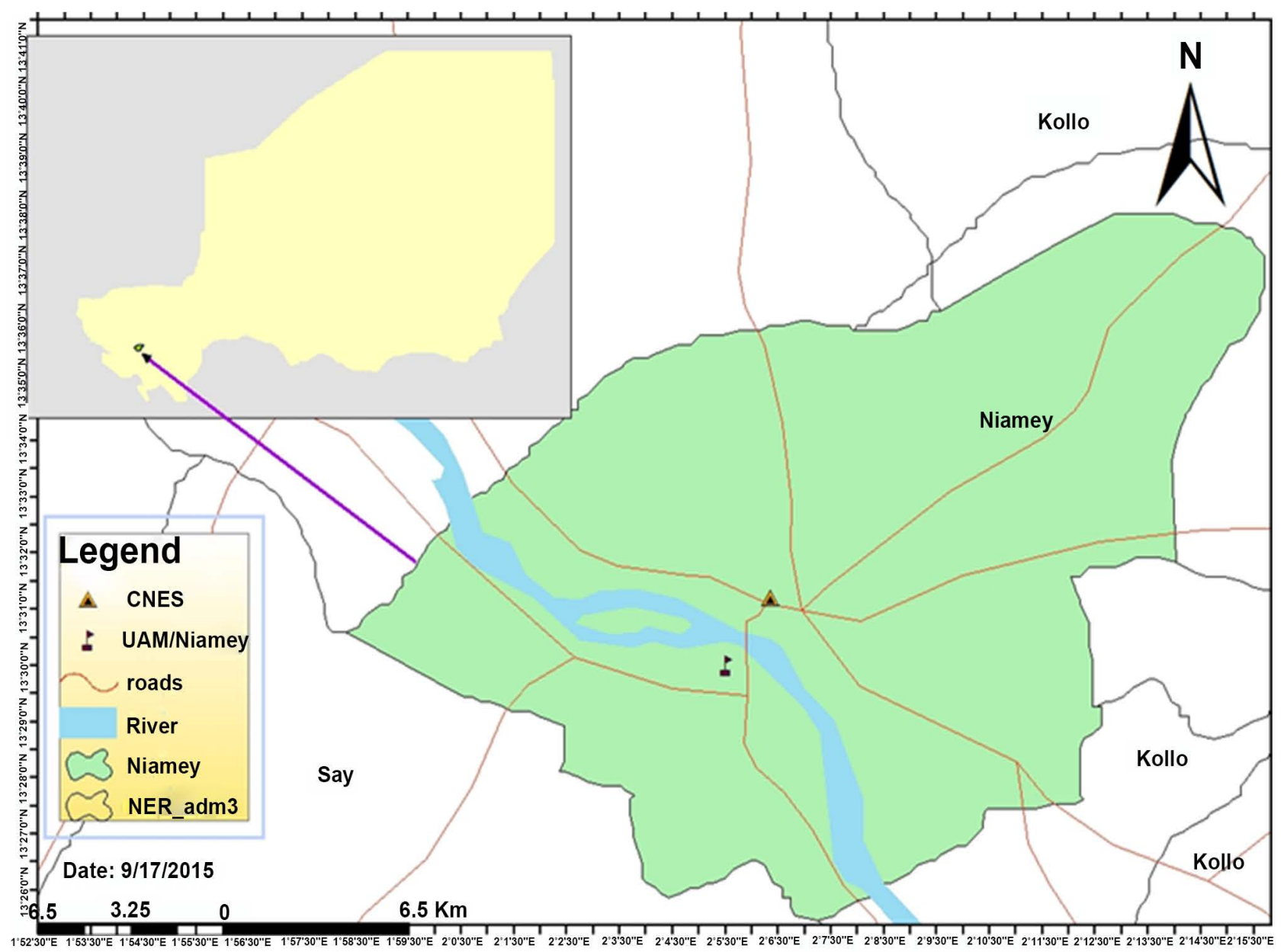

Figure 1. Map of study area [9].
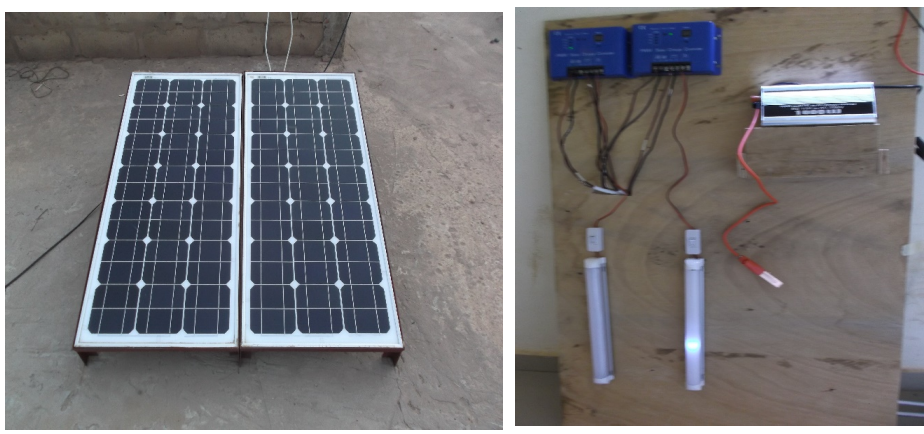

Figure 2. Experimental set up [9].

\subsubsection{Measurement and Data Processing}

Maximum output current and voltage of the PV module were measured and recorded daily at time interval of thirty minutes using a digital multi-meter for the months of April, May, June, and partly July and August. From these recorded values, daily average and monthly average values of maximum power were estimated using the following equation

$$
P_{P V}=I * V
$$




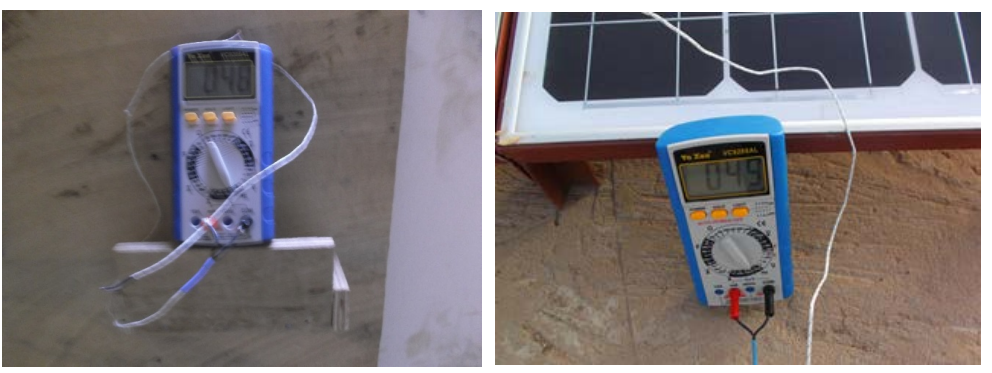

Figure 3. The digital multi-meter with a thermoelectric couple.

Table 1. Measurement errors of the various parameter.

\begin{tabular}{cccc}
\hline Parameters & DC Voltage & DC Current & Ambient Temperature \\
\hline Error & $1.4 \mathrm{mV}$ & $30 \mathrm{~mA}$ & $0.005^{\circ} \mathrm{C}$ \\
\hline
\end{tabular}

With $P_{P V}$ the power output of the $P V$ module, $I$ the output current, and the $V$ the output voltage.

Furthermore, the daily energy produced by the PV module from 7 AM to 6:30 PM was estimated using the following equation:

$$
E_{d}=\sum_{t=7: 00}^{t=18: 30} P(t) * 0.5
$$

where $E_{d}$ is the daily energy produced by the PV module in Watt-hour/day, $P(t)$ is the PV output power for a given time, 0.5 is the interval time in hour. From this result we easily estimated the daily PV output energy in watt-hour per square meter (Watt-hour $/ \mathrm{m}^{2} /$ day) generated by this particular module and also the average daily energy for each month (from April to August) using the Equation (3).

$$
\bar{E}_{d}=\frac{\sum_{i=1}^{i=n} E_{d i}}{n}
$$

With $\bar{E}_{d}$, the average daily energy and $\mathrm{n}$ the number of days in the month.

\subsubsection{Measurement of Temperature}

A digital multi-meter is used to measure the ambient temperature. This aims to study the relationship between ambient temperature and the PV output parameters. For that, the rotary switch is set at TEMP position and the key type thermoelectric couple is connected to "V" and "COM" jacks. The zero (initial value) is between $18^{\circ} \mathrm{C}$ to $28^{\circ} \mathrm{C}$ according to the relative humidity of the area. To get the real temperature, we subtracted the initial value from the display temperature value in degree Celsius.

\subsubsection{Measurement and Data Processing}

The correlation coefficient designed by the letter $r$ is a coefficient that illustrates a quantitative measure of some correlation and dependence, meaning statistical relationships between two or more random variables or observed data values. In this study the Pearson's correlation coefficient given by the Equation (4) will be used to quantify the statistical relationships between the PV output power and the different parameters such as solar radiation and dust. 


$$
r=r_{p x}=\frac{\sum_{i=1}^{n}\left(P_{i}-\bar{P}\right)\left(X_{i}-\bar{X}\right)}{\sqrt{\sum_{i=1}^{n}\left(P_{i}-\bar{P}\right)^{2}} * \sqrt{\sum_{i=1}^{n}\left(X_{i}-\bar{X}\right)^{2}}}
$$

Where $\mathrm{r}$ is the correlation coefficient ranging from -1 to $+1, P_{i}$ is the PV output power at a given instant, $\bar{P}$ is the average $\mathrm{PV}$ output power, $X_{i}$ and $\bar{X}_{i}$ is the parameter and the average value of the parameter being correlated with the PV output power respectively.

If $r$ is closer to zero (0), there is no correlation or the correlation is weak. A perfect correlation \pm 1 occurs when the data point all lie on a straight line. If $r=$ +1 , the slope of this line is positive and we have a positive correlation. In contrast, if $r=-1$ the slope of the line is negative, so we have a negative correlation. For the values of $r$ closer to one (1) the correlation is said to be strong.

\section{Results, Analyses, and Discussion}

This chapter will present and analyze the effects of solar radiation, temperature, dust and cloud cover on PV power production and its efficiency as well as the daily and monthly average of the PV output power. Then the interpretation of these results will end the chapter.

\subsection{Profile of Solar Irradiation and Ambient Temperature}

The Figure 4 below shows the daily average profile of solar irradiation and ambient temperature. On the graph of solar irradiation (left) one can notice that all the months have the same pattern of variation with the maximum in April and minimum in August. Indeed, August represents the rainy month over the study area with cloudy sky that blocks the incoming solar radiation.

\subsection{Impact of Ambient Temperature on the Power Output and Efficiency}

High temperature decreases the output power and the conversion efficiency of the module. Indeed the slope of the output power and the conversion efficiency
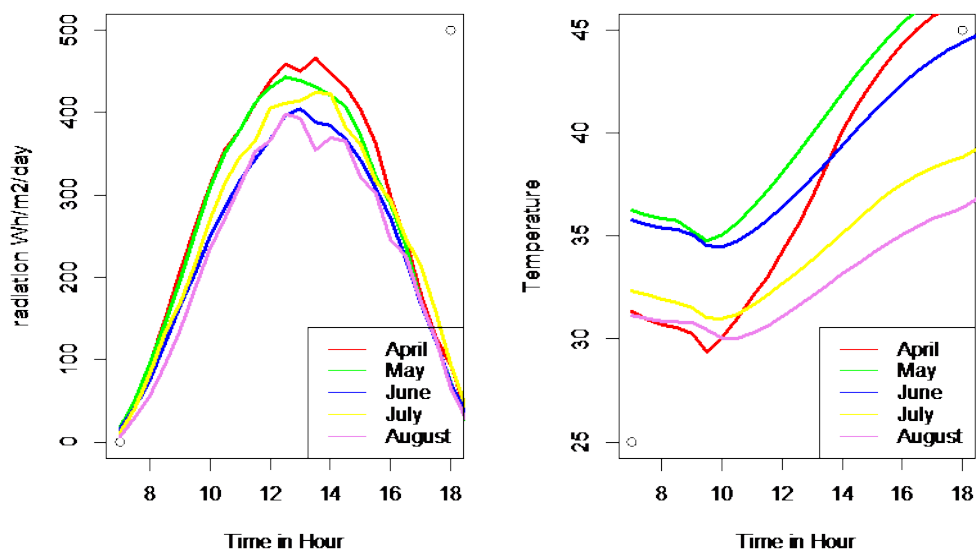

Figure 4. Average daily variation of solar irradiation and ambient temperature. 
are $-2.6 \mathrm{~W} /{ }^{\circ} \mathrm{C}$ and $-0.49 /{ }^{\circ} \mathrm{C}$ respectively. In other terms it means that the output power and the conversion efficiency decrease by $2.6 \mathrm{~W}$ and $0.49 \%$ respectively when the temperature increases by $1^{\circ} \mathrm{C}$. The Figure 5 shows the graph of the efficiency and output power against the temperature. From this graph it is clearly shown that the increase in ambient temperature has a negative impact on both the output power and the conversion efficiency.

This is due to the fact that, when the temperature increases, the output current increases slightly with high decrease of output voltage because of its exponential behavior vis a vis of the ambient temperature. As a result, the overall power decreases and also the conversion efficiency.

The Table 2 summarizes the maximum, minimum, average temperature and conversion efficiency from April to August.

From this table above, we observe three maximum conversion efficiency and (April, June, and July) and three minimum conversion efficiency (May, July, and August).

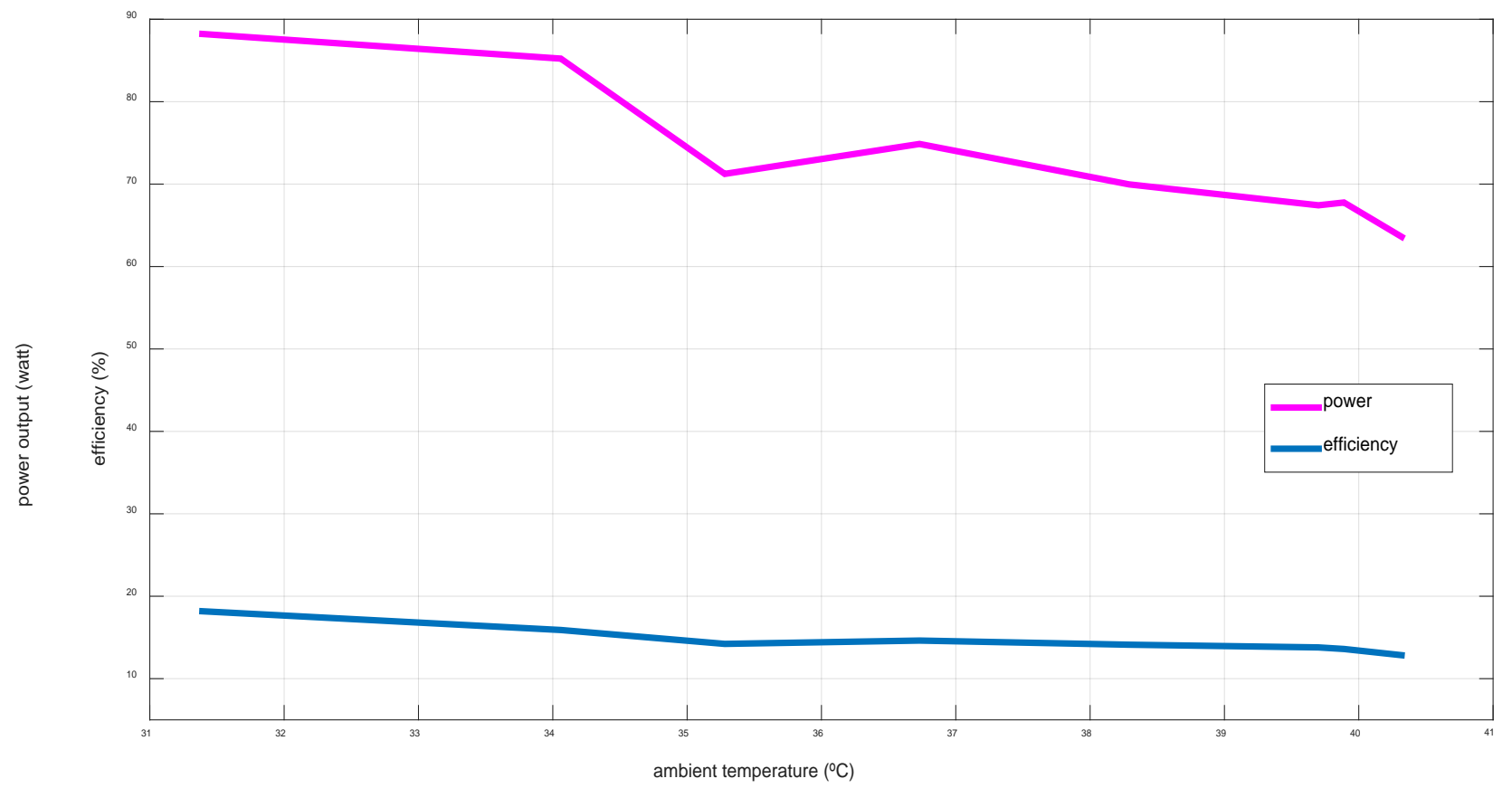

Figure 5. effect of ambient temperature on conversion efficiency and PV output power.

Table 2. Summary of maximum and minimum values of ambient temperature and efficiency.

\begin{tabular}{ccccccc}
\hline \multirow{2}{*}{ Months } & \multicolumn{3}{c}{ Ambient temperature $\left({ }^{\circ} \mathrm{C}\right)$} & \multicolumn{3}{c}{ Conversion efficiency $(\%)$} \\
\cline { 2 - 7 } & Maximum & Minimum & Average & Maximum & Minimum & Average \\
\hline April & 39.1 & 36.01 & 37.4 & 16.31 & 12.99 & 14.09 \\
May & 43.02 & 36.7 & 40.4 & 14.54 & 11.51 & 12.81 \\
June & 40.7 & 32.8 & 38.5 & 16.24 & 11.62 & 13.67 \\
July & 38.76 & 30.4 & 34.2 & 17.10 & 10.88 & 14.08 \\
August & 39.65 & 28.9 & 32.9 & 14.92 & 10.61 & 12.66 \\
\hline
\end{tabular}




\subsection{Impact of Dust Accumulation on the Performance of Solar PV Module}

In order to quantify the impacts of dust accumulation on the performance of the PV module, two solar modules have been used. One of the modules is cleaned every morning and the other one is left dirty. The output current, voltage was recorded every thirty minutes. This allows estimating the derived parameters such as power output, daily energy yielded and the conversion efficiency of the two solar modules.

The Figures 6-8 show the impact of dust on the output current, voltage, power, conversion efficiency and the daily energy yielded.

\subsubsection{Impacts on PV Current and Voltage}

The dust accumulation has great impacts on the performance of solar PV. It affects the output parameters that are the electrical current and the voltage. The graphs below show the impacts of dust on the output current and voltage.

\subsubsection{Impact on PV Power Output and Conversion Efficiency}

The impacts of dust accumulation on the performance of power output and conversion efficiency are shown in the Figure 7.

\subsubsection{Impacts on the Daily Energy Output}

The Figure 8 shows the relative variation of the daily energy output and conversion efficiency caused by dust accumulation. From this graph, it is clearly shown that this variation increase with time.

The general trend is that the energy output and efficiency decrease with time of exposure. However, we were not able to establish a coherent relationship between dust accumulation and time because of other parameters such as wind and rain. Indeed, in a windy and rainy days, the dust accumulated on the PV module is watched out and thus reducing the dust impacts on the daily energy output.

The daily energy obtained for the two solar PV modules after twenty-three days of are summarized in the Table 3.
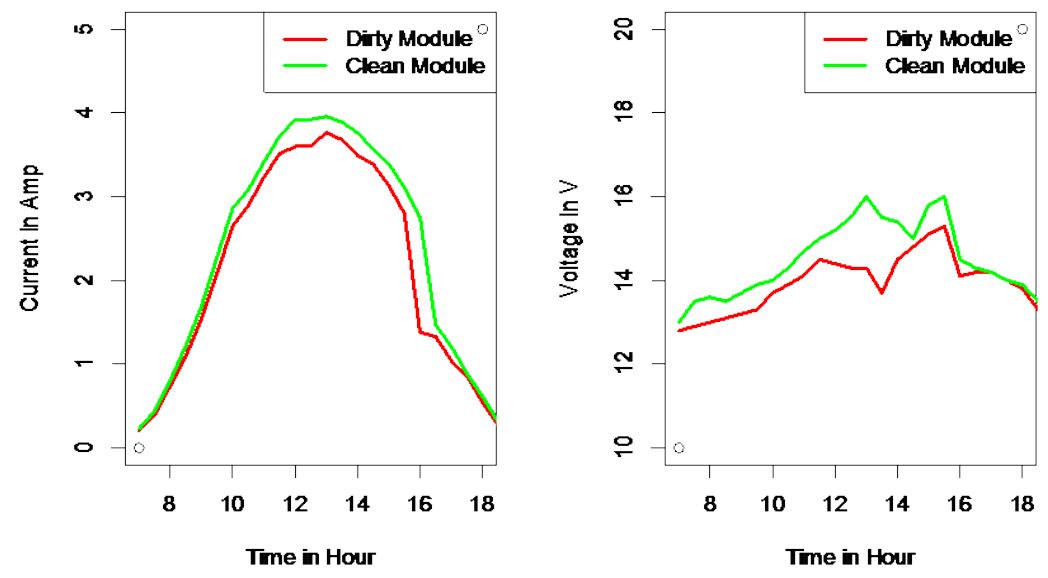

Figure 6. Dust accumulation impacts on the output current and voltage. 

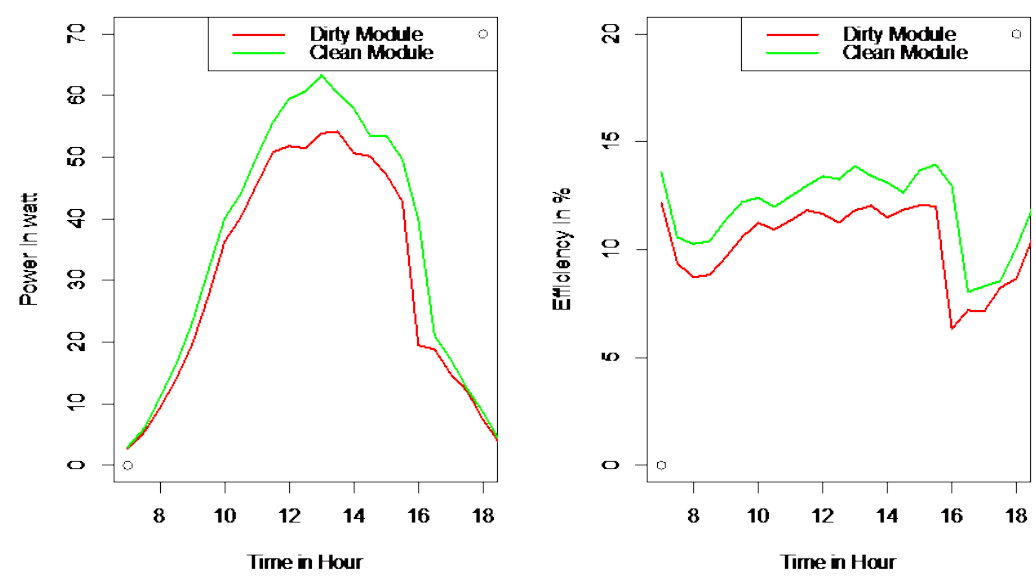

Figure 7. Dust accumulation impacts on the power output and conversion efficiency.
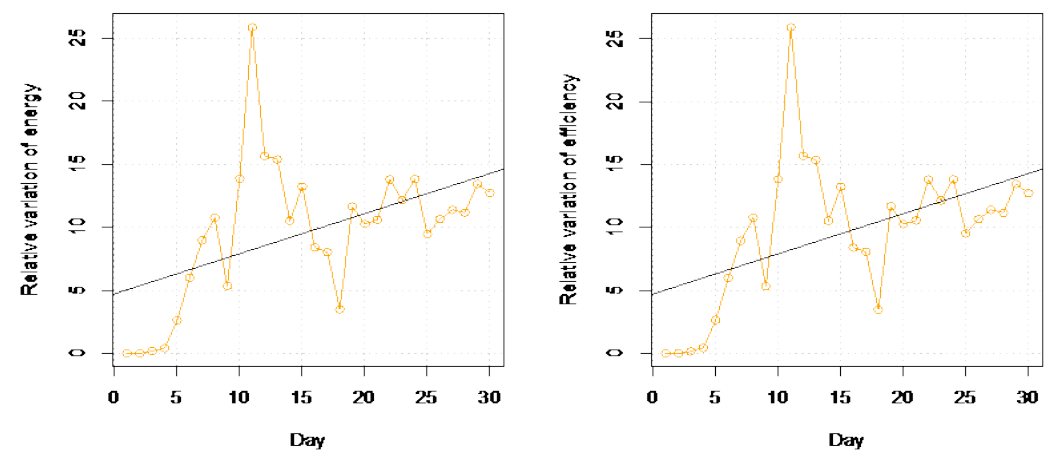

Figure 8. Impacts of dust on the energy output.

Table 3. Daily energy output of clean and unclean module on June 232015.

\begin{tabular}{cc}
\hline PV Module & Daily energy output \\
\hline Clean module & 484 \\
Unclean module & 410
\end{tabular}

From these tables, the daily output is reduced by $15.28 \%$ after 23 days of exposure, which is very significant corresponding to $0.66 \%$ per day.

\subsection{Impacts of Relative Humidity and Cloud Cover on the Performance of Solar PV Module}

The Figure 9 and Figure 10 show the effect of cloud cover and relative humidity on the daily profile of $\mathrm{PV}$ power output.

From the graph, of Figure 9, it is observed that on cloudy the daily profile for solar irradiance, ambient temperature is perturbed. These perturbations have great impacts on the performance of the solar module by weakening the output power and the conversion efficiency of the solar module.

During sunny and clear sky days the incoming solar radiation is not perturbed (smooth profile) and the maximum values of irradiance and power are obtained 

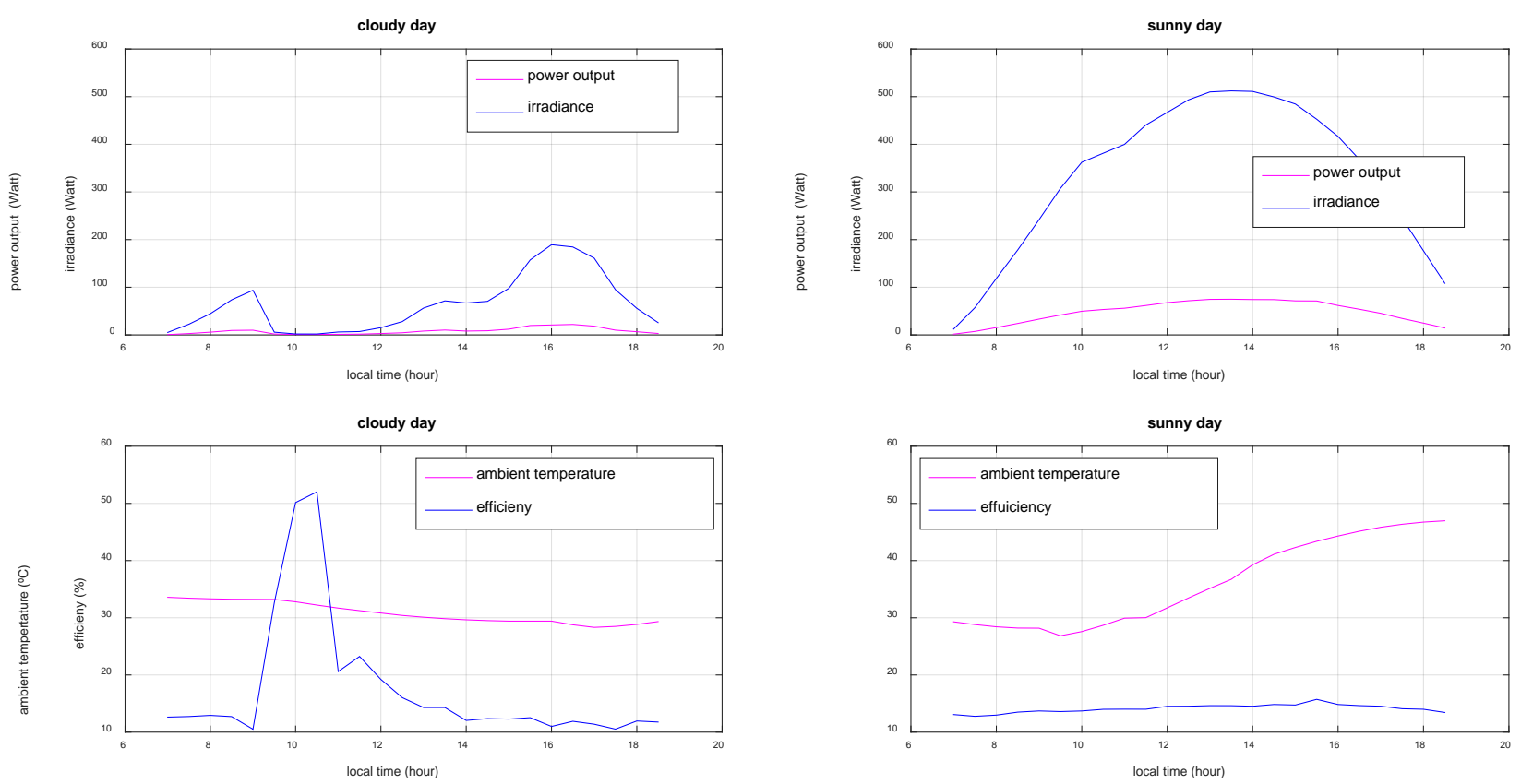

Figure 9. Cloud cover impacts on the performance of solar module.

\section{Energy vs RH}

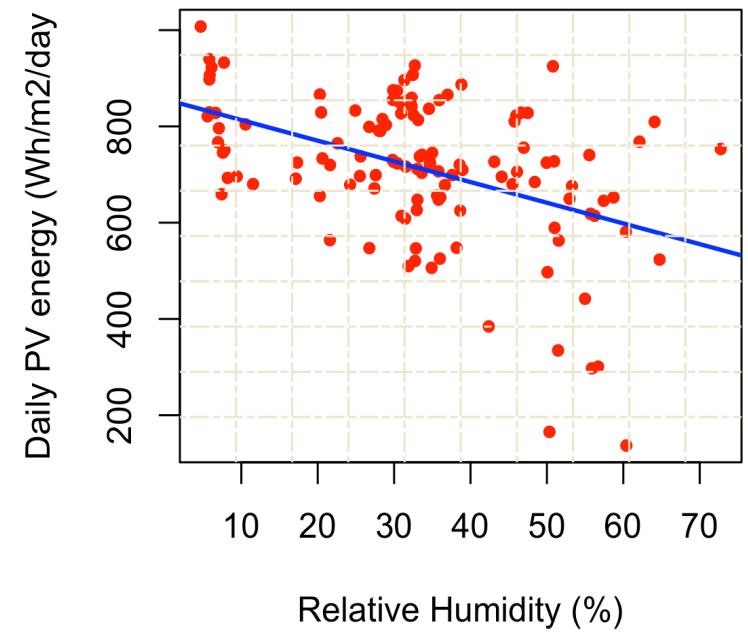

Figure 10. Relative humidity impacts on the performance of the PV module.

at solar noon resulting to a smooth profile of ambient temperature and conversion efficiency. In contrast, in cloudy and rainy days, the observations are different due to high cloud intermittent.

On the graph of Figure 10, it is observed a decreasing trend of daily energy when relative humidity increases. This can explain by the fact that high relative humidity may participate to three different scenarios: diffraction, reflection and absorption of solar irradiance. As a result the solar PV energy is reduced, as light equals power. 


\subsection{Average Daily Profile of Power Output and Conversion Efficiency}

The Figure 11 shows the variation of the power output and the conversion efficiency for the months April, May, June, July, and August. From these graphs, it is clearly observed that both the highest values of the power output and conversion efficiency are obtained around solar noon for all the months. However, in July and August the curves of power output and conversion efficiency show many fluctuations compared to the other months with quiet smooth and stables curves. Furthermore, in July, between 4 and 5 PM, the efficiency curve shows a strong decrease in efficiency due to the higher frequency of clouds around this particular time.

\subsection{Daily Energy Yielded by the PV Module under Niamey's Environment}

In order to classify the different months in terms of daily energy output it is important to know the average values of each month. The Table 4 shows the average daily solar radiation and solar PV energy from April to August. From this table, it is clearly observed that the highest daily energy production on average is obtained in April (around $850 \mathrm{Wh} / \mathrm{m}^{2} /$ day) and the lowest in August (below 700 $\mathrm{Wh} / \mathrm{m}^{2} /$ day). The lower values of PV energy recorded in May and August are attributed to higher values of ambient temperature and lower values of solar irradiance respectively. The lower values of solar radiation in August are caused by the high occurrence of cloud during this month.

The Figure 12 gives the daily energy yielded from 7 AM to 63 PM for the months of April, May, June, July, and August.
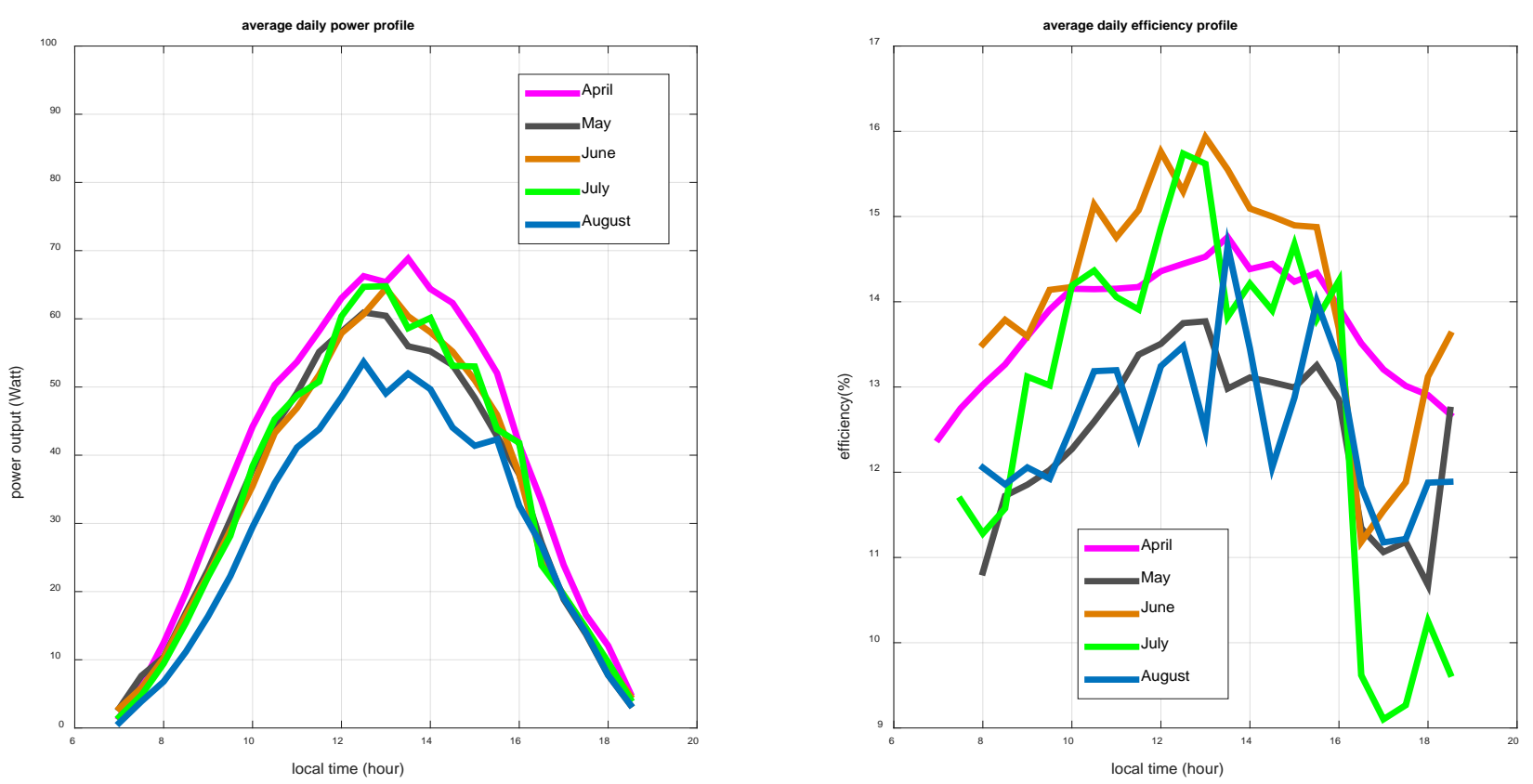

Figure 11. Average daily variation of power output and conversion efficiency. 


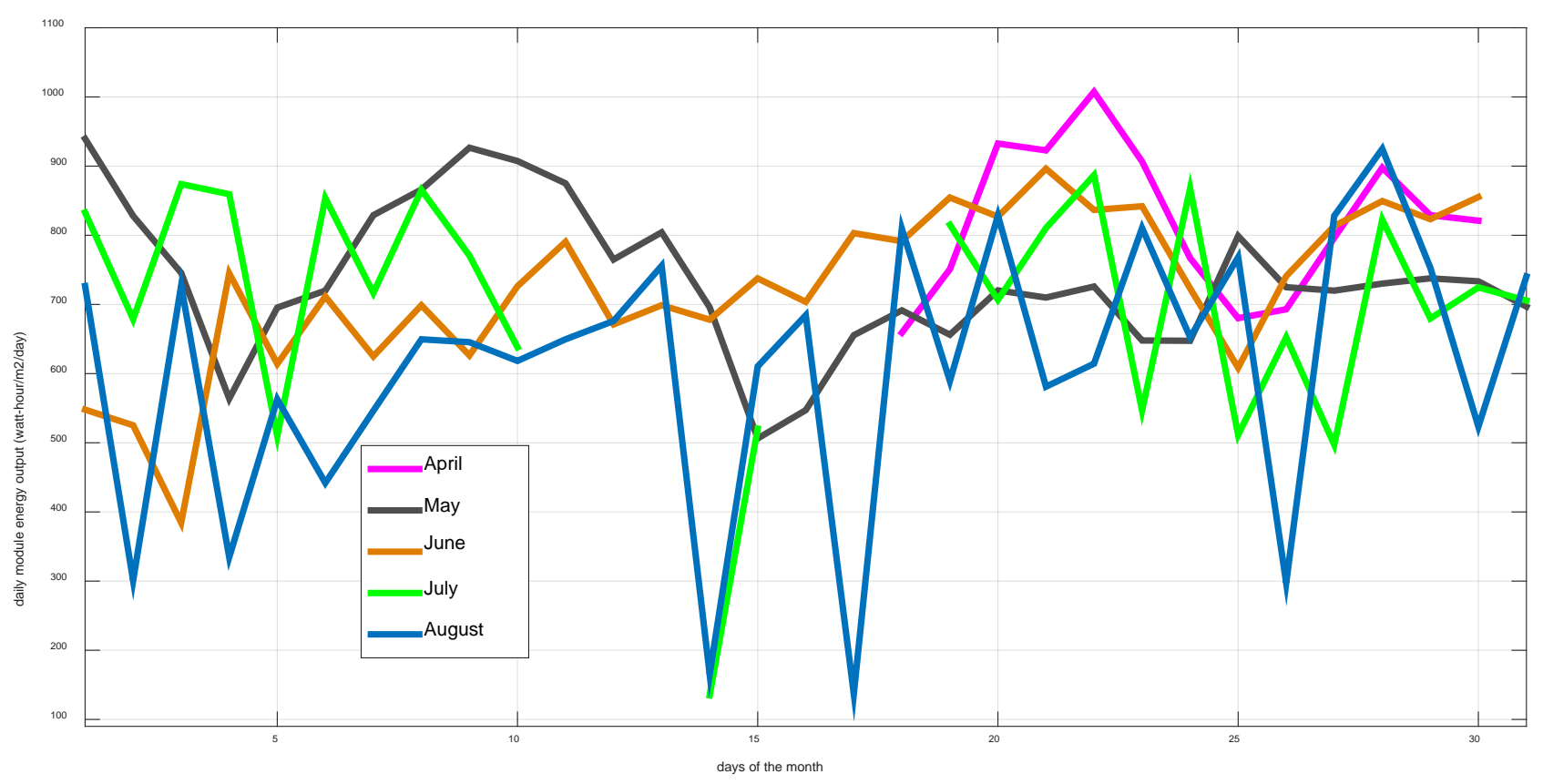

Figure 12. Daily PV energy yielded for months of April, May, June, July, and August.

Table 4. Average solar radiation and PV energy.

\begin{tabular}{ccc}
\hline Months & Solar Radiation $\left(\mathrm{Wh} / \mathrm{m}^{2} /\right.$ day $)$ & PVenergy $\left(\mathrm{Wh} / \mathrm{m}^{2} /\right.$ day $)$ \\
\hline April & 5809 & 820 \\
May & 5576 & 736 \\
June & 5305 & 725 \\
July & 5403 & 728 \\
August & 4856 & 605 \\
\hline
\end{tabular}

\section{Discussions of Results}

The impact of ambient temperature on solar PV module has shown that for an increase of $1^{\circ} \mathrm{C}$, a decrease of $2.6 \mathrm{~W}$ of power output corresponding to $2.6 \%$. Concerning to the module efficiency, an increase of $1^{\circ} \mathrm{C}$ induced a decrease of $0.49 \%$. However, in theory, a value of $0.4 \%$ reduction in power output for an increase of $1^{\circ} \mathrm{C}$ has been found by [10]. This difference between the obtained value and the theoretical value is mainly due to climatic conditions of the study area. Nevertheless, some similar works have been done throughout the world. The results show also the same decreasing trend of power output and efficiency with the increase of temperature [7] [11] [12]. However, this result is not in line with the one found in the work Ref. [6] that showed the PV module is favorable to high temperature study in tropical area.

Regarding to the relative humidity, the results of this work has shown also a decrease in energy with increase of humidity. This can be attributed to the fact that during high relative humidity the atmosphere contains a wide range of water vapor particles sizes. So when light hits the water droplets, three scenarios 
may happen. It may be refracted, reflected, or diffracted. These effects plunge the reception level of the direct component of the solar irradiance impacting on the output power and on the daily energy output of the PV module. Similar results were found in the work of Ref. [8] [13].

The dust accumulation also has a great impact on the power output of the module. Indeed, up to $10 \%$ reduction in power has been observed for only 23 days. Similar works have been also carried out to assess dust accumulation impact on the power output of the solar PV modules. In Pakistan, Ali et al found for a period of three months, $20 \%$ and $16 \%$ decrease of output power for the mono-crystalline and polycrystalline modules respectively [14]. The same work has been done in Senegal for one year without cleaning the PV modules and that resulted to a loss of $18 \%$ and $78 \%$ for the polycrystalline and mono-crystalline respectively [15].

The daily energy of the clean module is higher than the unclean one. Exposure of the module in June within 23 days without cleaning it has reduced the daily energy output by $15.29 \%$. Similar effects of dust accumulation on the PV energy have been also found in other parts of the world; $32 \%$ reduction was found in Saudi Arabia [16]. Another study carried out by Hassan et al. showed a reduction ranging from $33.5 \%$ to $65.8 \%$ for a period of one to six months respectively [17]. In the tropical climate of Thailand, $11 \%$ of reduction has been observed for the period of one month [18]. Then in United States, an average reduction of 1 to $4.7 \%$ in a two months' period has been reported by [19]. All these results show that the impacts of dust on the performance of solar PV module vary from one location to another. Hence, this requires different studies at different sites.

\section{Conclusions and Recommendations}

This paper presented the effects of environmental parameters on the performance of the PV module in Niamey and the average daily energy output produced by the mono-crystalline solar module on a tilted surface of $15^{\circ}$ facing south. So the results show that the effect of dust and temperature are more noticeable in May and June. But in July and August, the cloud shadow and relative humidity are the parameters that have great impact on the energy output of PV module. The dust haze also has impact on the global solar radiation by weakening its direct component and also on the PV performance by enhancing the dust accumulation onto the module.

So depending on time scale, one can rank the different parameters that impact the performance of solar PV in Niamey. In a shorter term, cloud cover, relative humidity, and ambient temperature have the greatest impacts whereas in a longer-term dust accumulation has the greatest impact.

So for the future research, the following recommendations are suggested:

Performing the measurement on a moving position using a solar tracker.

Perform the measurement for all the months of the year in order to characterize the different seasons in terms of PV output potential. 
Measuring the PV output power, solar irradiance, relative humidity, and wind speed, ambient temperature at the same time will improve the correlation coefficient results.

Use different types of PV module technologies in the market to compare the impact of dust, temperature, on their performance in order to know which one of these technologies is more suitable for the local environment.

\section{Declaration}

The authors declare that there is not conflict of interest regarding the publication of this paper. The mentioned received funding in the acknowledgement section did not lead to any conflict of interests regarding the publication of this manuscript.

\section{Acknowledgements}

First of all we would like to acknowledge with thanks the BMBF, the Germany Federal Ministry of Education and Research and the West African Science Service Centre on Climate Change and Adapted Land Uses (WASCAL) for providing us the scholarship and financial support during our Master Research Program. This work is a contribution of the West African Science Service Center in Climate Change and Adapted Land Uses (WASCAL)-MRP Climate Change and Energy of University Abdou Moumouni, Niamey (Niger). We would like also to dedicate this paper to the memory of Prof. ABDOULAYE Alassane the first Director of WASCAL Master Research Program on Climate Change and Energy of University Abdou Moumouni.

\section{References}

[1] Twidel, J. and Weir, T. (2015) Renewable Energy Resourcecs. Routledge, London and New York.

[2] Hill, R. (1999) Prospects for Photovoltaic. Energy Wprld, 208, 8-11.

[3] Martinot, Martinot, E., Mastny, L., Rosbotham, L., Suding, P. and Lempp, P. (2009) Renewable Global Status. REN21. http://www.ren21.net/status-of-renewables/global-status-report/

[4] Singh, G., Alzouma Nouhou, S. and Youba, S. (2013) Niger, Renewable Readness assessment. IREN, Niamey.

[5] Bücher, K. (1997) Site Dependence of the Energy Collection of PV Modules. Solar Energy Materials and Solar Cells, 47, 85-94. https://doi.org/10.1016/S0927-0248(97)00028-7

[6] Sanusi, Y., Fajinmi, G. and Babatunde, E. (2011) Effects of Ambient Temperature on the Performance of a Photovoltaic Solar Systems in a Tropical Area. The Pacific Journal of Science and Technology, 12, 176-180.

[7] Fesharaki, J., Dehgani, M., Fesharaki, J. and Tavasoli, H. (2011) Effect of Temperature on Photovoltaic Cell Efficiency. Proceedings of the First International Conference on Emerging Trends in Energy Conservation, Teheran, 20-21 November 
2011, 20-21.

[8] Mekhilef, S., Saidur, R. and Kamalisar, M. (2012) Effect of Dust, Humidity, and Air Velocity on Efficiency of Solar Photovoltaic Cells. Renewable and Saistainable Energy Review, 16, 2920-2925. https://doi.org/10.1016/j.rser.2012.02.012

[9] Abdou Latif, B., Madougou, S. and Rabani, A. (2017) Impacts of Cloud Cover and Dust on the Performance of Solar Module in Niamey. Journal of Renewable Energy, 2017, 8.

[10] Hausler, T. and Rogass, H. (2000) Latent Heat Storage. Sixteenth European Photovoltaic Solar Energy Conference, Glasgow, May 2000, 2265-2267.

[11] Al-Sabounchi, A. (1998) Effect of Temperature on the Demanded of Solar Cells at Different Inclinations. Renewable Energy, 14, 149-155. https://doi.org/10.1016/S0960-1481(98)00061-5

[12] Nishioka, K., Hatayama, T., Uraoka, Y., Fuyuki, T., Hagihara, R. and Watanabe, M. (2003) Field Test Analysis of PV System Output Characteristics Focusing on Module Temperature. Solar Energy Materials and Solar Cells, 75, 665-671. https://doi.org/10.1016/S0927-0248(02)00148-4

[13] Touati, F.A., Al-Hitmi, M.A. and Bouchech, H.J. (2013) Study of the Effects od Dust, Relative Humidity, and Temperature on Solar PV Performance in Doha: Comparison between Monocrystalline and Amorphous PVS. International Journal of Green Energy, 10, 680-689. https://doi.org/10.1080/15435075.2012.692134

[14] Ali, H., Zafar, M., Nasir, M., Ali, M. and Siddiqui, M. (2015) Effect of Dust Deposition on the Performance of Photovoltaic Modules in Taxila, Pakistan. Thermal Science, 21, 915-923. https://doi.org/10.2298/TSCI140515046A

[15] Ndiaye, A., Kebe, C., Ndiaye, P., Charki, A., Kobi, A. and Sambou, V. (2013) Impacts of Dust on the Photovoltaic (PV) Module Characteristics after an Exposition of One Year in Sahelian Environment: The Case of Senegal. International Journal of Physical Sciences, 8, 1166-1173.

[16] Mani, M. and Pillai, R. (2010) Impacts of Dust on Solar Photovoltaic (PV) Performance: Research Status, Challenges and Recommendations. Renewables and Saistainable Energy Reviews, 14, 3124-3131. https://doi.org/10.1016/j.rser.2010.07.065

[17] Hassan, A., Rahoma, U., Elminir, H. and Fathy, A. (2005) Effect of Airborn Dust Concentration on the Performance of the PV Modules. Journal of Atronomical Society of Egypt, 13, 24-38.

[18] Mastekbayeva, G. and Kumar, S. (2000) Effect of Dust on the Transmittance of Low Density Polyethylene Glazing in a Tropical Climate. Solar Energy, 68, 135-141. https://doi.org/10.1016/S0038-092X(99)00069-9

[19] Hottel, H. and Woertz, B. (1942) Performance of Flat-Plate Solar Heat Collectors. Trans. ASME (Am. Soc. Mech. Eng.), 64. 